\title{
The Resveratrol-induced Relaxation of Cholecystokinin Octapeptide- or KCl-induced Tension in Male Guinea Pig Gallbladder Strips Is Mediated Through L-type $\mathrm{Ca}^{2+}$ Channels
}

\author{
Loren W Kline ${ }^{1 *}$ and Edward Karpinski ${ }^{2}$ \\ Departments of ${ }^{1}$ Dentistry and ${ }^{2}$ Physiology, University of Alberta, Edmonton, Alberta, Canada
}

\section{Background/Aims}

Resveratrol (3,5,4'-trihydroxystilbene) is a polyphenolic compound (stilbene) and a phytoalexin. The purpose of this study was to determine the mechanism which mediated the resveratrol-induced relaxation of cholecystokinin octapeptide- or $\mathrm{KCl}$-induced tension in male guinea pig gallbladder strips.

\section{Methods}

Gallbladder strips were prepared and suspended in in vitro chambers filled with Krebs-Henseleit solution. The strips were attached to force displacement transducers, and the changes in tension were recorded on a polygraph. All reagents were added directly into the chambers.

\section{Results}

To determine if intracellular $\mathrm{Ca}^{2+}$ release mediated the resveratrol-induced relaxation of cholecystokinin octapeptide-induced tension, 2-aminoethoxydiphenylborane $(2-A P B)$ was used. 2-APB significantly $(P<0.01)$ decreased the amount of RSVL-induced relaxation. To determine if protein kinase $A$ (PKA) mediated the resveratrol-induced relaxation, PKA inhibitor 14-22 amide myristolated (PKA-IM) was used. PKA-IM had no effect on resveratrol-induced relaxation. Neither KT5823, NG-methyl-L-arginine acetate salt, a nitric oxide synthase inhibitor, nor fulvestrant had a significant effect on the amount of resveratrol-induced relaxation. Genistein, a protein tyrosine kinase inhibitor, significantly $(P<0.01)$ increased the RSVL-induced relaxation. To determine if protein kinase $C$ mediated the RSVL-induced relaxation, the protein kinase $C$ inhibitors bisindolymaleimide IV and chelerythrine $\mathrm{Cl}$ - were used together, and a significant $(P<0.05)$ increase in resveratrol-induced relaxation was observed. The pretreatment of the strips with resveratrol significantly $(P<0.001)$ decreased the amount of $\mathrm{KCl}$ - and cholecystokinin octapeptide-induced tension.

\section{Conclusions}

Resveratrol-induced relaxation is mediated by its effects on $\mathrm{L}$-type $\mathrm{Ca}^{2+}$ channels and intracellular $\mathrm{Ca}^{2+}$ release.

(J Neurogastroenterol Motil 2015;21:62-68)

Key Words

Calcium channels; Gallbladder; Muscle, smooth; Phytoalexins; Resveratrol

Received: August 13, 2014 Revised: October 21, 2014 Accepted: October 28, 2014

(c) This is an Open Access article distributed under the terms of the Creative Commons Attribution Non-Commercial License (http://creativecommons. org/licenses/by-nc/3.0) which permits unrestricted non-commercial use, distribution, and reproduction in any medium, provided the original work is properly cited.

*Correspondence: Loren W Kline, PhD

Department of Dentistry, University of Alberta, Edmonton, Alberta T6G 2E1, Canada

Tel: +1-780-492-4468, Fax: +1-780-492-7466, E-mail: Ikline@ualberta.ca

Financial support: None.

Conflicts of interest: None.

Author contributions: Edward Karpinski helped the experiments, assisted in writing the manuscript, and assited in the interpretation of the data. ORCID: Loren W Kline, http://orcid.org/0000-0002-4735-6296. 


\section{Introduction}

Resveratrol (3,5,4'-trihydroxystilbene, RSVL) is a phytoalexin produced by plants in response to damage, particularly in grapevines and peanuts. ${ }^{1,2}$ RSVL has been shown to be a non-flavonoid phytoestrogen, and to act as an estrogen receptor agonist in MCF-7 cells transiently transfected with estrogen-responsive reporter constructs. ${ }^{3}$ RSVL has similar effects in breast cancer cells expressing mutant and wild-type estrogen receptors. ${ }^{4}$ Levenson et $\mathrm{al}^{5}$ found that RSVL acted as an estrogen receptor agonist in breast cancer cells stably transfected with estrogen receptor $\alpha$.

RSVL can modulate nitric oxide (NO) levels by its action on both endothelial nitric oxide synthase (eNOS) and cytokine-inducible nitric oxide synthase (iNOS). RSVL can cause NOmediated relaxation of precontracted endothelium-intact rat aorta through an increase of NO via eNOS. ${ }^{6-9}$ RSVL decreased $\mathrm{Ca}^{2+}$ sensitivity but did not affect $\mathrm{KCl}$-stimulated intracellular $\mathrm{Ca}^{2+}$ increases in vascular smooth muscle of rat aorta. ${ }^{10} \mathrm{RSVL}$ also increases the amount of cGMP in sheep coronary arteries. This triggers vasorelaxant responses even in endothelium-disrupted arteries. ${ }^{11}$ RSVL prevented bradykinin-induced contraction of rat urinary bladder smooth muscle by the inhibition of $\mathrm{Ca}^{2+}$ influx. ${ }^{12}$ Wang et $\mathrm{al}^{13}$ showed that RSVL had an inhibitory effect on guinea pig gallbladder contractility. The present study determined which mechanisms mediated the relaxation effect of RSVL on cholecystokinin octapeptide (CCK) and $\mathrm{KCl}$-induced tension in male guinea pig gallbladder strips.

\section{Materials and Methods}

The Animal Care Committee-Health Sciences of the University of Alberta approved the experiments performed by issuing protocol number (\#275) on February 6, 2014. The experiments used male Hartley guinea pigs (200-375 g body weight) which were killed by decapitation. The gallbladder was removed, cleansed, and placed in Krebs-Henseleit solution that was gassed with $95 \% \mathrm{O}_{2}$ and $5 \% \mathrm{CO}_{2}$. The composition of the KrebsHenseleit solution was $\mathrm{NaCl}, 115 \mathrm{mM}$; $\mathrm{KCl}, 5 \mathrm{mM} \mathrm{CaCl}_{2}, 2.1$ mM; $\mathrm{MgSO}_{4}, 1.2 \mathrm{mM} ; \mathrm{NaH}_{2} \mathrm{PO}_{4}, 1.2 \mathrm{mM} ; \mathrm{NaHCO}_{3}, 25$ $\mathrm{mM}$; and glucose, $11 \mathrm{mM}$. Strips $(1.5 \times 0.5 \mathrm{~cm})$ were made from each gallbladder which were maintained in Sawyer-Bartlestone chambers filled with Krebs-Henseleit solution, maintained at $37^{\circ} \mathrm{C}$, and gassed with $95 \% \mathrm{O}_{2}$ and $5 \% \mathrm{CO}_{2}$. An optimum resting tension of $0.7 \mathrm{~g}$ was determined previously and used in the study. ${ }^{14,15}$

A Grass 7D polygraph (Grass Instruments Co., Quincy MA, USA) and Grass FT03 force displacement transducers were used to measure the force developed by the gallbladder strips. Isolated strips were equilibrated in the chambers for 45 minutes prior to determining their suitability for use. Each chamber had $2 \mu \mathrm{M}$ (final concentration) of atropine added in every experiment, 3 minutes prior to $1 \mathrm{nM} \mathrm{CCK}$. The tension measurement was followed by 3 changes of Krebs-Henseleit solution. The test was repeated twice with 25 minutes between tests. A repeatable minimum active tension of $0.5 \mathrm{~g}$ had to be generated by the strips before use. All agents used were added directly to the chambers. All concentrations are reported as the final concentration in the chambers.

Several series of experiments were performed to examine the effects of RSVL on the tension generated by the gallbladder strips. CCK $(1 \mathrm{nM})$ produced a stable long lasting tension after 3 minutes. This steady tension lasted at least 10 mintes. ${ }^{14,15}$ In order to determine if RSVL could relax CCK- or $\mathrm{KCl}$-induced tension, concentration response curves were generated. The strips were exposed to 1 concentration of RSVL (10, 50, 100, or 250 $\mu \mathrm{M})$, the response was observed until the relaxation reached a steady level (approximately 5 minutes), the Krebs-Henseleit solution was changed 3 times, and the strips were allowed to recover for 30 minutes before testing different concentrations of RSVL. The concentration of RSVL ( $75 \mu \mathrm{M})$ was selected for use in subsequent experiments as it produced a reproducible relaxation. The same procedure was followed to generate a concentration response curve using $40 \mathrm{mM} \mathrm{KCl}$ instead of $1 \mathrm{nM} \mathrm{CCK}$. The use of $\mathrm{KCl}$ to directly depolarize smooth muscle is a standard procedure.

The concentration of each blocker used in the experiments was 5 times the half maximal inhibitory concentration $\left(\mathrm{IC}_{50}\right)$. In order to determine if the $\mathrm{Ca}^{2+}$ released from the endoplasmic reticulum mediated the RSVL-induced relaxation 2-aminoethoxydiphenylborane (2-APB, $125 \mu \mathrm{M})$, a cell permeable inhibitor of inositol 1,4,5-triphosphate ( $\mathrm{IP}_{3}$ )-induced $\mathrm{Ca}^{2+}$ release, was added to the chambers 10 minutes prior to the CCK. The CCK was then added to the chambers. When the tension reached a steady level, $75 \mu \mathrm{M}$ RSVL was added to the chambers. The amount of relaxation was observed. The amount of relaxation observed when RSVL only was used, was then compared to the amount of relaxation observed when the strips were treated with $2-\mathrm{APB}$ and RSVL. This procedure was followed with each agent used. 
Protein kinase A inhibitor 14-22 amide myristolated (a protein kinase inhibitor, PKA-IM; $180 \mathrm{nM}$ ), KT5823 (a protein kinase $\mathrm{G}[\mathrm{PKG}]$ inhibitor, $585 \mathrm{nM}$ ), and genistein (a tyrosine kinase inhibitor, $10 \mu \mathrm{M}$ ) were added to the chambers 5 minutes prior to the addition of CCK.

The PKC inhibitors, chelerythrine $\mathrm{Cl}^{-}(5 \mu \mathrm{M})$ and bisindolymaleimide IV (BisIV, $0.5 \mu \mathrm{M}$ ), were used together to determine the effects of PKC on RSVL-induced relaxation of $\mathrm{CCK}$ - or $\mathrm{KCl}$-induced tension. They were added to the chambers 5 minutes prior to either $\mathrm{CCK}$ or $\mathrm{KCl} . \mathrm{N}^{\mathrm{G}}$-methyl-L-arginine acetate salt $(20 \mu \mathrm{M})$ was used to determine if $\mathrm{NO}$ mediated the RSVL -induced relaxation. Fulvestrant $(10 \mu \mathrm{M})$, an estrogen receptor blocker, was used to determine if RSVL might act via estrogen receptor activation.

In order to determine if RSVL inhibited extracellular $\mathrm{Ca}^{2+}$ entry, $40 \mathrm{mM} \mathrm{KCl}$ was used to induce tension in the strips. After the amount of tension generated by the $40 \mathrm{mM} \mathrm{KCl}$ was recorded, the Krebs-Henseleit solution was changed 3 times and the strips allowed to equilibrate for 25 minutes. The $75 \mu \mathrm{M}$ RSVL was then added to the chambers 3 minutes prior to the addition of $40 \mathrm{mM} \mathrm{KCl}$. The amount of tension generated was recorded and compared to that observed when the $\mathrm{KCl}$ was added to the chambers with no RSVL. The same experiments were performed using CCK, i.e., adding RSVL 3 minutes prior to the addition of $\mathrm{CCK}$

The following agents were purchased from Sigma (St. Louis, MO, USA): CCK, atropine, $\mathrm{N}^{\mathrm{G}}$-methyl-L-arginine acetate salt, fulvestrant, and bisindolymaleimide IV. The following agents were purchased from Calbiochem (LaJolla, CA, USA): PKA-IM, KT5823, chelerythrine $\mathrm{Cl}^{-}$, genistein, and 2-APB. Trans-resveratrol was purchased from Cayman Chemical (Ann Arbor, MI, USA). All agents were dissolved in either distilled water or dimethyl sulfoxide. The amount of dimethyl sulfoxide $(10 \mu \mathrm{L})$ added to the chambers was determined to have no effect on the strips.

\section{Statistical Methods}

Statistical comparisons were done using the paired $t$ test. Results are expressed as mean $\pm \mathrm{SE}$ Differences among mean values with $P<0.05$ were considered significant. The number of gallbladders (animals) used in each experiment are indicated by "n". Each gallbladder was used to prepare 4 strips; hence, an n of 4 means up to 16 strips were used.

\section{A}
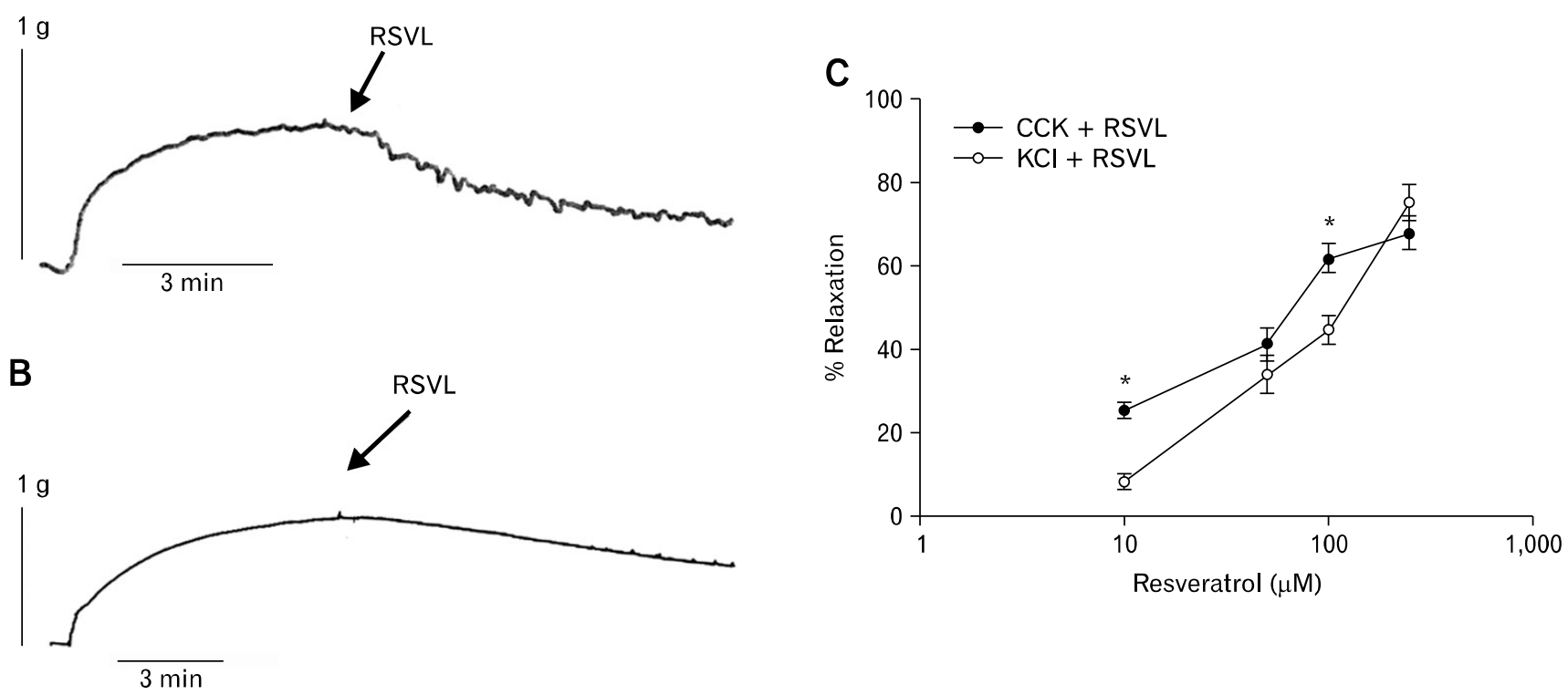

Figure 1. Effect of resveratrol (3,5,4'-trihydroxystilbebe, RSVL) on cholecystokinin octapeptide (CCK)- or KCl-induced tension. (A) A data trace showing the relaxation caused by RSVL on CCK-induced tension in a male guinea pig gallbladder strip. (B) A data trace showing the relaxation caused by RSVL on KCl-induced tension in a male guinea pig gallbladder strip. (C) RSVL $(10 \mu \mathrm{M}$ and $100 \mu \mathrm{M})$ produced significantly $\left({ }^{*} P<0.01, \mathrm{n}=\right.$ 20) more relaxation in the CCK-induced tension (filled circles) than $\mathrm{KCl}$-induced tension (open circles). When $75 \mu \mathrm{M}$ or $250 \mu \mathrm{M}$ RSVL was used, there was no significant difference in the amount of RSVL-induced relaxation when CCK and $\mathrm{KCl}$ were compared. The significance was determined by paired $t$ tests. 


\section{Results}

RSVL induced a concentration dependent relaxation in both CCK- and $\mathrm{KCl}$-induced tension (Fig. 1). RSVL at $10 \mu \mathrm{M}$ and $100 \mu \mathrm{M}$ significantly $(P<0.01, \mathrm{n}=20)$ relaxed the CCK-induced tension more than $\mathrm{KCl}$-induced tension. When $75 \mu \mathrm{M}$ or $250 \mu \mathrm{M}$ RSVL was used, there was no significant difference in the amount of RSVL-induced relaxation when $\mathrm{CCK}$ and $\mathrm{KCl}$ were compared. There was no significant difference between the amount of CCK-induced tension and the $\mathrm{KCl}$-induced tension (1 $\mathrm{nM}$ CCK, $0.86 \pm 0.05 \mathrm{~g}$ vs $40 \mathrm{mM} \mathrm{KCl}, 0.88 \pm 0.06 \mathrm{~g} ; \mathrm{n}=8)$.

The use of 2-APB, an inhibitor of $\mathrm{IP}_{3}$-induced $\mathrm{Ca}^{2+}$ release, caused a significant $(P<0.001)$ decrease in the amount of CCK-induced tension $(0.79 \pm 0.05 \mathrm{~g}$ vs $0.31 \pm 0.03 \mathrm{~g}, \mathrm{n}=6)$. When the strips were treated with $2-\mathrm{APB}$, there was a significant $(P<0.05)$ decrease in the amount of relaxation observed between the strips not treated and treated with 2-APB (59.7 \pm $3.6 \%$ vs $45.9 \pm 5.6 \%, \mathrm{n}=6$; Fig. 2). When PKA-IM was used, no significant effect was observed on the amount of CCK-in-

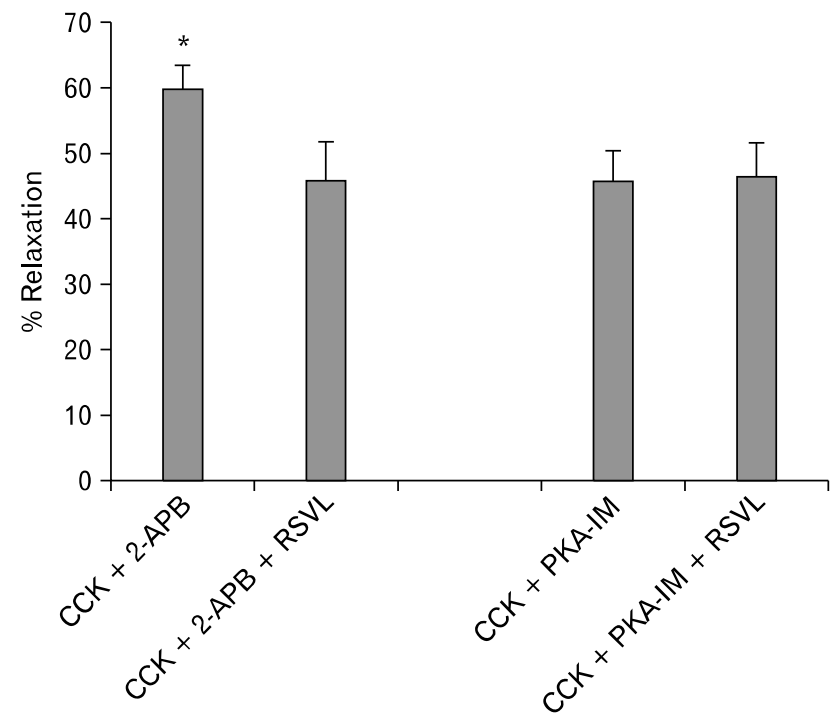

Figure 2. Effect of intracellular $\mathrm{Ca}^{2+}$ release or protein kinase A (PKA) inhibition on resveratrol (3,5,4'-trihydroxystilbene, RSVL)induced relaxation. When the strips were treated with 2 -aminoethoxydiphenylborane $(2-\mathrm{APB})$, there was a significant $\left({ }^{*} P<0.05\right)$ decrease in the amount of relaxation observed between the strips not treated and treated with 2-APB $(n=6)$. When the PKA inhibitor 14-22 amide myristolated (PKA-IM), was used, no significant effect was observed on the amount of cholecystokinin octapeptide (CCK)-induced tension; nor was there a significant effect on the amount of RSVL-induced relaxation $(n=6)$. duced tension ( $0.75 \pm 0.05 \mathrm{~g}$ vs $0.8 \pm 0.05 \mathrm{~g}, \mathrm{n}=5)$; nor was there a significant effect on the amount of RSVL-induced relaxation $(45.7 \pm 4.5 \%$ vs $46.5 \pm 5.0 \%, \mathrm{n}=5)$. Treatment of the strips with KT5823, a PKG blocker, significantly $(P<0.01)$ increased the amount of CCK-induced tension $(0.77 \pm 0.06 \mathrm{~g}$ vs $0.86 \pm 0.06 \mathrm{~g}, \mathrm{n}=4)$. KT5823 did not have a significant effect on the amount of RSVL-induced relaxation of CCK-induced tension $(48.1 \pm 4.0 \%$ vs $50.3 \pm 5.2 \%, \mathrm{n}=4$; Fig. 3$)$.

Genistein significantly $(P<0.01)$ increased effect on the amount of RSVL-induced relaxation of CCK-induced tension (53.4 $\pm 2.2 \%$ vs $61.8 \pm 3.8 \%, \mathrm{n}=4$; Fig. 3$)$. There was no significant difference in the amount of CCK-induced tension $(0.79$ $\pm 0.06 \mathrm{~g}$ vs $0.74 \pm 0.06 \mathrm{~g})$.

When the PKC blockers, BisIV and chelerythrine $\mathrm{Cl}^{-}$were used in combination, a significant increase $(P<0.05)$ in the amount of RSVL-induced relaxation $(61.8 \pm 3.5 \%$ vs $73.7 \pm$ $5.6 \%, \mathrm{n}=4$; Fig. 4) was observed; however, there was no significant effect on the amount of CCK-induced tension $(0.64 \pm$ $0.04 \mathrm{~g}$ vs $0.68 \pm 0.04 \mathrm{~g})$.

The use of $\mathrm{N}^{\mathrm{G}}$-methyl-L-arginine acetate salt, a NO synthase blocker, did not have a significant effect on either the CCK-induced tension or the RSVL-induced relaxation (48.1 \pm

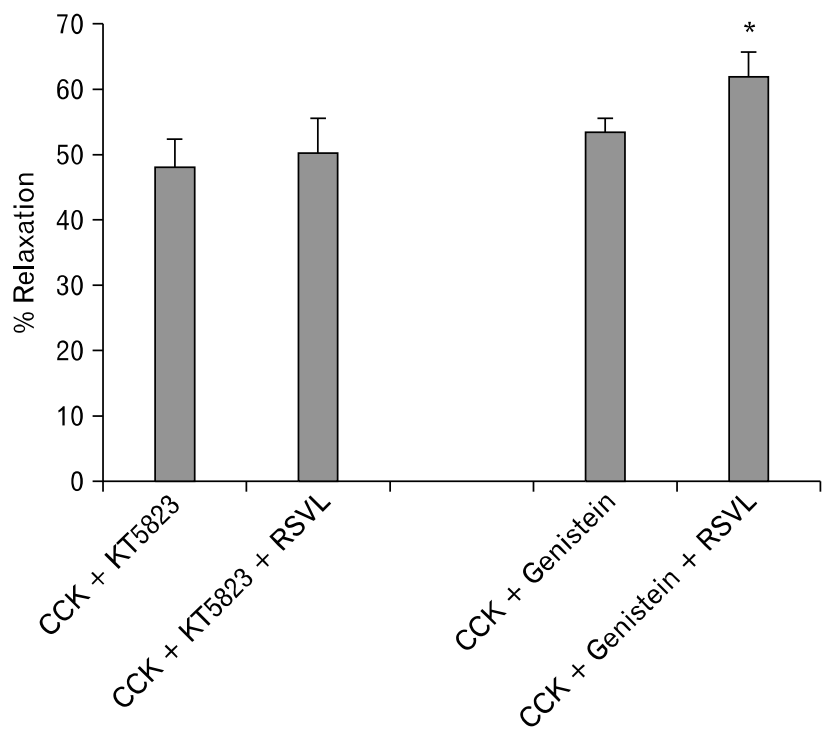

Figure 3. The effect of protein kinase $\mathrm{G}(\mathrm{PKG})$ blocking or protein tyrosine kinase blocking of resveratrol (3,5,4'-trihydroxystilbene, RSVL)induced relaxation. KT5823 (585 nM), a PKG inhibitor, did not have a significant effect on the amount of RSVL-induced relaxation of cholecystokinin octapeptide (CCK)-induced tension $(n=4)$. Genistein $(10 \mu \mathrm{M})$ significantly $\left({ }^{*} P<0.01\right)$ increased effect on the amount of RSVL-induced relaxation of CCK-induced tension $(n=4)$. 


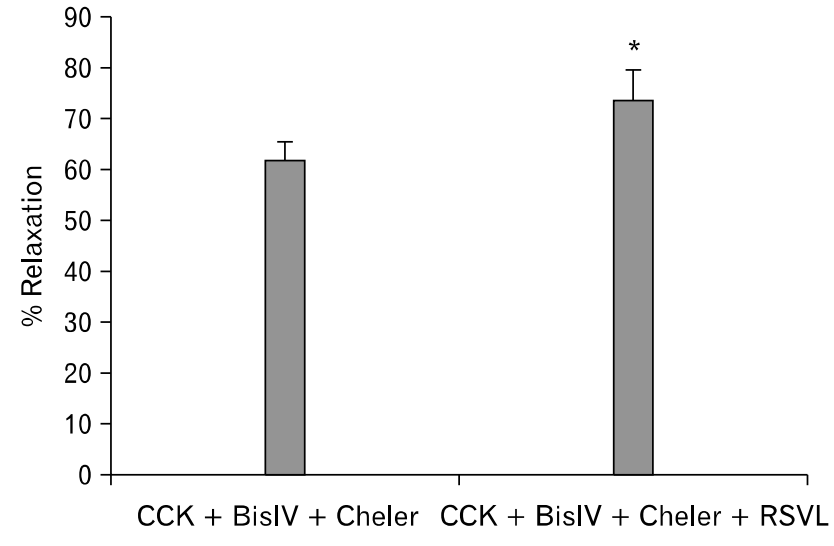

Figure 4. The effect of protein kinase $\mathrm{C}$ (PKC) blocking on resveratrol (3,5,4'-trihydroxystilbene, RSVL)-induced relaxation. The use of the PKC inhibitors bisindolymaleimide IV (BisIV, $0.5 \mu \mathrm{M}$ ) and chelerythrine $\mathrm{Cl}^{-}$(Cheler, $\left.5 \mu \mathrm{M}\right)$ significantly $(P<0.05 ; \mathrm{n}=4)$ increased the amount of RSVL-induced relaxation.

$3.4 \%$ vs $44.6 \pm 3.2 \%, \mathrm{n}=4$ ). The use of the estrogen receptor blocker fulvestrant did not have a significant effect on the amount of CCK-induced tension (CCK + RSVL, $0.84 \pm 0.09 \mathrm{~g}$ vs fulvestrant $+\mathrm{CCK}+\mathrm{RSVL}, 0.81 \pm 0.08 \mathrm{~g} ; \mathrm{n}=5$ ). Fulvestrant also had no significant effect in the amount of RSVL-induced relaxation $(\mathrm{CCK}+\mathrm{RSVL}, 50.9 \pm 3.8 \%$ vs fulvestrant $+\mathrm{CCK}+$ RSVL, $50.2 \pm 5.2 \% ; \mathrm{n}=5$ ).

When RSVL was added to the chambers 3 minutes prior to the addition of $\mathrm{KCl}$, there was a significant decrease $(P<0.001)$ in the amount of tension generated $(0.85 \pm 0.06 \mathrm{~g}$ vs $0.42 \pm 0.04$ $\mathrm{g}, \mathrm{n}=5$. Fig. 5). When $75 \mu \mathrm{M}$ RSVL was added to the chambers 3 minutes prior to the addition of CCK $(1 \mathrm{nM})$, there was a significant $(P<0.001)$ decrease in the amount of tension generated $(0.56 \pm 0.05 \mathrm{~g}$ vs $0.34 \pm 0.05 \mathrm{~g}, \mathrm{n}=3$; Fig. 5$)$.

\section{Discussion}

RSVL is a non-flavonoid phytoestrogen that can act as an estrogen receptor agonist in MCF-7 cells and breast cancer cells. ${ }^{3,4}$ Strips of either male or female guinea pig gallbladder strips are sensitive to both $17 \beta$-estradiol and progesterone. Both $17 \beta$-estradiol and progesterone relaxed both $\mathrm{CCK}$ - and $\mathrm{KCl}$-induced tensions using different signaling pathways. ${ }^{16-18}$ The current experiments demonstrated that RSVL relaxed both CCK- and $\mathrm{KCl}$-induced tensions in a concentration-dependent manner. The use of fulvestrant demonstrated that this effect of RSVL was not mediated through estrogen receptors which had been suggested by other researchers. ${ }^{3-5}$

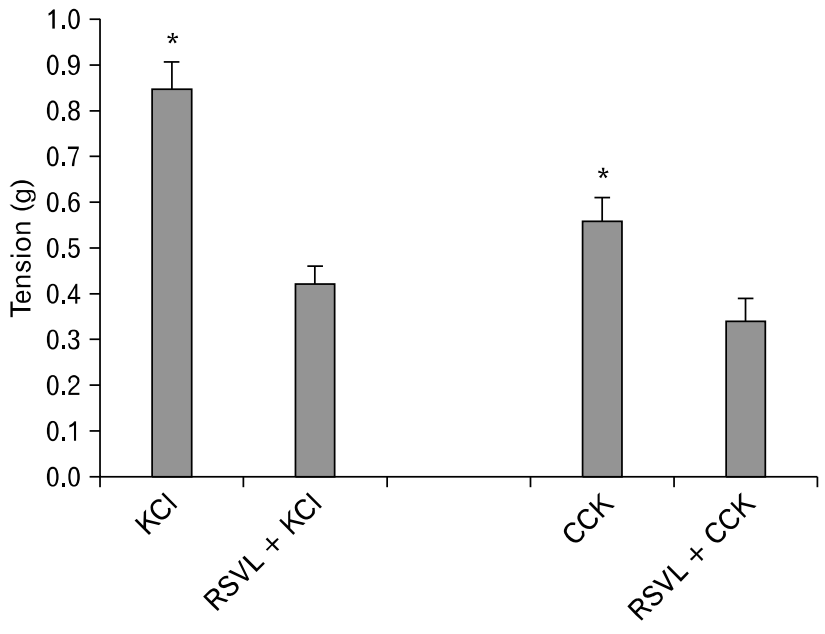

Figure 5. The effect of resveratrol (3,5,4'-trihydroxystilbene, RSVL) on cholecystokinin octapeptide (CCK)- or $\mathrm{KCl}$-induced tension. When RSVL $(75 \mu \mathrm{M})$ was added to the chambers 3 minutes prior to the addition of $\mathrm{KCl}$ there was a significant decrease $\left({ }^{*} P<0.001\right)$ in the amount of tension generated $(\mathrm{n}=5)$. When $75 \mu \mathrm{M}$ RSVL was added to the chambers 3 minutes prior to the addition of CCK $(1 \mathrm{nM})$, there was a significant $\left({ }^{*} P<0.001\right)$ decrease in the amount of tension generated $(\mathrm{n}=3)$.

El Mowafy ${ }^{11}$ showed that RSVL increased cGMP in sheep coronary arteries which led to an endothelium-independent vasodilation. In the guinea pig gallbladder strips the use of KT5823, a PKG antagonist, had no significant effect on the amount of RSVL-induced relaxation.

RSVL acted through NO release from endothelium-intact blood vessels. ${ }^{6-9}$ The use of $\mathrm{N}^{\mathrm{G}}$-methyl-L-arginine acetate salt reported here showed that inhibiting NO synthase had no significant effect on the RSVL-induced relaxation.

BisIV and chelerythrine $\mathrm{Cl}^{-}$are PKC inhibitors. Using BisIV and chelerythrine $\mathrm{Cl}^{-}$in together produced consistent results. ${ }^{14,15}$ The PKC inhibitors significantly increased the amount of RSVL-induced relaxation. Wu et al, ${ }^{19}$ using the patchclamp technique, demonstrated that gallbladder contraction required increasing $\mathrm{Ca}^{2+}$ influx through L-type $\mathrm{Ca}^{2+}$ calcium channels via a PKC pathway. Zhu et $\mathrm{al}^{20}$ showed that sulfated CCK prompted contraction of guinea pig proximal colon smooth muscle strips via activation of the $\mathrm{IP}_{3}-\mathrm{PKC}$ signal transduction pathway. Activation of PKC leads to an increase in L-channel opening which would lead to a decrease in RSVL-induced relaxation. Blocking PKC with BisIV and chelerythrine $\mathrm{Cl}^{-}$ would lead to a decrease in L-channel opening which would lead to an increase in RSVL-induced relaxation. This is what was observed in the guinea pig gallbladder strips. In addition, using 
PKA-IM did not have a significant effect on the amount of RSVL-induced relaxation. Thus, the PKA did not mediate the RSVL-induced relaxation.

Protein tyrosine kinase may have a role in gallbladder smooth muscle contractility. In guinea pig gallbladder strips, genistein, a protein tyrosine kinase inhibitor, significantly decreased the progesterone-induced relaxation, with no effect on the CCK-induced tension. ${ }^{16}$ Alcón et $\mathrm{al}^{21}$ demonstrated that vanadate activated the tyrosine kinase pathway in guinea pig gallbladder smooth muscle. When genistein was used in the current study, genistein significantly increased the amount of RSVL-induced relaxation. Genistein has been shown to inhibit peristalsis in guinea pig small intestine by inhibiting intracellular signaling cascades involving protein kinases that act on the contractile apparatus in smooth muscle. $^{22}$ The genistein-induced inhibition of protein tyrosine kinase in addition to the actions of RSVL may have led to the increased relaxation.

The role of extracellular $\mathrm{Ca}^{2+}$ entry to initiate CCK-induced tension was reported by $\mathrm{Cl}_{\text {as }}$ et $\mathrm{al}^{23}$ and Parkman et $\mathrm{al}^{24} \mathrm{Nifedi-}$ pine almost completely abolished spontaneous interdigestive gallbladder contractile activity and decreased resting gallbladder tone. This suggested that extracellular $\mathrm{Ca}^{2+}$ entry was important in gallbladder motiltity. Quinn et $\mathrm{al}^{25}$ reported that extracellular $\mathrm{Ca}^{2+}$ entry was required for intracellular $\mathrm{Ca}^{2+}$ release which was required for the sustained contraction of the gallbladder. Balemba et $\mathrm{al}^{26}$ demonstrated that spontaneous electrical rhythmicity in guinea pig gallbladder smooth muscle cells depended upon $\mathrm{Ca}^{2+}$ entry via voltage-dependent $\mathrm{Ca}^{2+}$ channels and then on $\mathrm{Ca}^{2+}$ mobilization from the sarcoplasmic reticulum via $\mathrm{IP}_{3}$ channels. $\mathrm{KCl}$ was used to directly depolarize the gallbladder strips. RSVL, when added to the chambers prior to $\mathrm{KCl}$, significantly decreased the amount of $\mathrm{KCl}$-induced tension. Therefore, blocking of L-type $\mathrm{Ca}^{2+}$ channels mediated part of the RSVL-induced relaxation. RSVL had the same effect on CCK-induced tension. Since RSVL significantly decreased the amount of both $\mathrm{KCl}$ - and CCK-induced tension when added to the chambers prior to either agonist, it suggested that RSVL exerts its effect in part by blocking L-type $\mathrm{Ca}^{2+}$ channels. It may also block intracellular $\mathrm{Ca}^{2+}$ release. Using 2-APB, an inhibitor of IP3-induced $\mathrm{Ca}^{2+}$ release, caused a significant decrease in the amount of RSVL-induced relaxation. This suggested that part of the RSVL effect was mediated through intracellular $\mathrm{Ca}^{2+}$ release.

The sustained phase of CCK-induced tension requires extracellular $\mathrm{Ca}^{2+}$ entry. ${ }^{16}$ The current study demonstrated that RSVL relaxed both CCK- and $\mathrm{KCl}$-induced tension in male guinea pig gallbladder strips. No second messenger systems studied produced a significant effect on the RSVL-induced relaxation. The adding of RSVL to the in vitro chambers before either $\mathrm{CCK}$ or $\mathrm{KCl}$ produced a decrease in the amount of tension generated which was significant. If the amount of tension generated by either agonist is significantly decreased when RSVL is added before either $\mathrm{CCK}$ or $\mathrm{KCl}$ and no second messenger system had an effect on the RSVL-induced relaxation, which was significant, then it can be concluded that RSVL exerts its effects by blocking L-type $\mathrm{Ca}^{2+}$ channels. The results of these experiments are similar to those reported for vascular smooth muscle cells and strips. ${ }^{17,27}$ In conclusion, the relaxation effect of RSVL was mediated primarily by its effects on both L-type $\mathrm{Ca}^{2+}$ channels and intracellular $\mathrm{Ca}^{2+}$ release.

\section{References}

1. Langcake P, Pryce RJ. The production of resveratrol by vitus vinifera and other members of the vitaceae as a response to infection or injury. Physiol Plant Pathol 1976;9:77-86.

2. Burns J, Yokota T, Ashihara H, Lean ME, Crozier A. Plant foods and herbal sources of resveratrol. J Agric Food Chem 2002;50:33373340 .

3. Gehm BD, McAndrews JM, Chien PY, Jameson JL. Resveratrol, a polyphenolic compound found in grapes and wine, is an agonist for the estrogen receptor. Proc Natl Acad Sci USA 1997;94:14138-14143.

4. Gehm BD, Levenson AS, Liu H, et al. Estrogenic effects of resveratrol in breast cancer cells expressing mutant and wild-type estrogen receptors: role of AF-1 and AF-2. J Steroid Biochem Mol Biol 2004;88:223-234.

5. Levenson AS, Gehm BD, Pearce ST, et al. Resveratrol acts as an estrogen receptor (ER) agonist in breast cancer cells stably transfected with ER. Int J Cancer 2003;104:587-596.

6. Chen CK, Pace-Asciak CR. Vasorelaxing activity of resveratrol and quercetin in isolated rat aorta. Gen Pharmacol 1996; 27:363-366.

7. Fitzpatrick DF, Hirschfield SL, Coffey RG. Endothelium-dependent vasorelaxing activity of wine and other grape products. Am J Physiol 1993;265(2 Pt 2):H774-H778.

8. Andriambeloson E, Kleschyov AL, Muller B, Beretz A, Stoclet JC, Andriantsitohaina R. Nitric oxide production and endothelium-dependent vasorelaxation by wine polyphenols in rat aorta. $\mathrm{Br} \mathrm{J}$ Pharmacol 1997;120:1053-1058.

9. Flesch M, Schwarz A, Bohm M. Effects of red and white wine on endothelium-dependent vasorelaxation of rat aorta and human coronary arteries. Am J Physiol 1998;275(4 Pt 2):H1183-H1190.

10. Buluc M, Demirel-Yilmaz E. Resveratrol decreases calcium sensitivity of vascular smooth muscle and enhances cytosolic calcium increase in endothelium. Vascul Pharmacol 2006;44:231-237.

11. El-Mowafy AM. Resveratrol activates membrane-found guanylyl cyclise in coronary arterial smooth muscle and a novel signaling mechanism in support of coronary protection. Biochem Biophys Res Commun 2002;291:1218-1224. 
12. Tsuda Y, Nakahara T, Mori A, Sakamoto K, Ishii K. Resveratrol prevents bradykinin-induced contraction of rat urinary bladder by decreasing prostaglandin production and calcium influx. Eur J Pharmacol 2011;666:189-195.

13. Wang, LD, Qiu XQ, Tian ZF, Zhang YF, Li HF. Inhibitory effects of genistein and resveratrol on guinea pig gallbladder contractility in vitro. World J Gastroenterol 2008;14:495 5-4960.

14. Kline LW, Kaneko T, Benishin CG, Pang PK. Calcitonin gene-related peptide: an inhibitor of gallbladder contraction. Can J Physiol Pharmacol 1991;69:1149-1154.

15. Kline LW, Karpinski E. 17 $\beta$-Estradiol relaxes cholecystokinin- and $\mathrm{KCl}$-induced tension in male guinea pig gallbladder strips. Steroids 2011;76:553-557.

16. Kline LW, Karpinski E. Progesterone inhibits gallbladder motility through multiple signalling pathways. Steroids 2005;70:673-679.

17. Kline LW, Karpinski E. Testosterone and dihydrotestosterone inhibit gallbladder motility through multiple signaling pathways. Steroids 2008;73:1174-1180.

18. Kline LW, Karpinski E. A comparison of the effects of various sex steroids on cholecystokinin- and $\mathrm{KCl}$-induced tension in female guinea pig gallbladder strips. Gen Comp Endocrinol 2013;185:37-43.

19. Wu ZX, Yu BP, Xia H, Xu L. Emodin increase $\mathrm{Ca}^{2+}$ influx through L-type $\mathrm{Ca}^{2+}$ channel in guinea pig gallbladder smooth muscle. Eur J Pharmacol 2008;595:95-99.

20. Zhu J, Chen L, Xia H, Luo HS. Mechanisms mediating CCK$8 \mathrm{~S}$-induced contraction of proximal colon in guinea pigs. World J
Gastroenterol 2010;16:1076-1085.

21. Alcón S, Camello PJ, García LJ, Pozo MJ. Activation of tyrosine kinase pathways by vanadate in gallbladder smooth muscle. Biochem Pharmacol 2000;59:1077-1089

22. Gharzouli K, Holzer P. Inhibition of guinea pig intestinal peristalsis by the flavonoids quercetin, naringenin, apigenin and genistein. Pharmacology 2004;70:5-14.

23. Clas D, Hould FS, Rosenthall L, Arzoumanian A, Fried GM. Nifedipine inhibits cholecystokinin-induced gallbladder contraction. J Surg Res 1989;46:479-483.

24. Parkman HP, Pagano AP, Ringold MA, Ryan JP. Effect of modulating voltage-dependent calcium channels on cholecystokinin and acetylcholine-induced contractions of the guinea pig gallbladder. Regul Pept 1996;63:31-37.

25. Quinn T, Mollay M. Smyth A, Baird AW. Capacitative calcium entry in guinea pig gallbladder smooth muscle in vitro. Life Sci 2004; 74:1659-1669.

26. Balemba OB, Salter MJ, Heppner TJ, Bonev AD, Nelson MT, Mawe GM. Spontaneous electrical rhythmicity and the role of the sarcroplasmic reticulum in the excitability of guinea gallbladder smooth muscle cells. Am J Physiol Gastrointest Liver Physiol 2006; 290:G655-G664.

27. Yu P, Harnett KM, Biancani P, De Petris G, Behar J. Interaction between signal transduction pathways contributing to gallbladder tonic contractions. Am J Physiol 1993;265(6 Pt 1):G1082-G1089. 